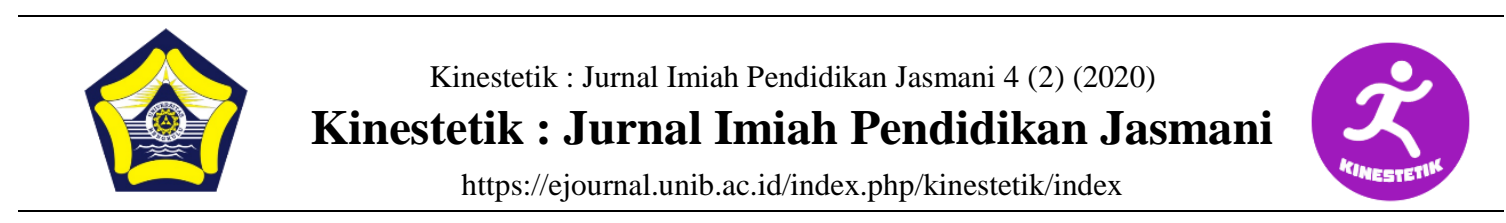

\title{
THE INFLUENCE OF FOREHAND GRIP HANDLING AND BACKHAND GRIP ON SHORT SERVICE ABILITY IN BADMINTON OF COLLAGE STUDENTS
}

\author{
Jufri $^{1}$, Ruslan $^{2}$, Rahmadi $^{3}$ \\ ${ }^{123}$ Universitas Mulawarman, Samarinda, Kalimantan Timur, Indonesia
}

\begin{tabular}{l}
\hline Article Info \\
\hline Article History: \\
Received August 2020 \\
Revised August 2020 \\
Accepted August 2020 \\
Available online September 2020 \\
\hline Keywords: \\
Forehand Grip, Backhand Grip, \\
Short Service \\
\hline
\end{tabular}

\begin{abstract}
\end{abstract}
This study aims to determine the effect of the handle on the short service ability of badminton games in Penjaskesrek students. This research is a pre-experiment, namely tow Group pretest-posttest design, the population in the study were 40 students of Physical Education Class 2017, Mulawarman University Samarinda. The data collection technique uses a short service test instrument, namely the forehand grip service test grip and the backhand grip handle. Based on the data analysis, the results obtained from the pretest average value of the forehand grip grip ability of 32.3500 , the average posttest value of the forehand grip grip of 52.6000, the value of $t$ count> is 7.818 , the significance value of the probability is 0.000 , and the $t$ table is 2.818. and the mean value of the backhand grip pre-test ability of 32.1500 , the average value of the backhand grip posttest of 48.1000 , the value of $t$ count $>$ of 10,747 , the significance value of the probability of 0.000 , and the $t$ table of 2,746 . the value of $t$ table 0.050 is greater than $t$ count 0.025 and the value of $\operatorname{sig}<\mathrm{a}(0.000<0.05)$, so it can be seen that Ho is accepted and $\mathrm{H} 1$ is accepted. This means that there is a significant effect of the effect of the forehand grip and the backhand grip of badminton on students by $95 \%$.

\footnotetext{
Corresponding address: Jl. Kuaro Jl. Tanah Grogot, Gn. Kelua, Kec. Samarinda Ulu, Kabupaten Paser, Kalimantan Timur 


\section{INTRODUCTION}

Badminton is one of the most famous sports in the world. This sport attracts various age groups, various skill levels, and both men and women play this sport indoors or outdoors for recreation as well as a competitive arena. Badminton is not only a recreational sport, but the emphasis is more on an achievement sport. As a form of activity or exercise given in play, the reference is to increase achievement. The development of badminton, especially in the East Kalimantan province, is quite encouraging. However, in the current era, the results shown by badminton players in East Kalimantan aren't in line by the situation in other areas, especially in Java. To play badminton, each individual's required to be able to master the technique properly and correctly. One of the factors that influence the success in playing badminton is the mastery and application of basic techniques effectively and efficiently.

Based on the observer, as long as the author conducted a survey during the badminton course for Physical Education student's class of 2017 Mulawarman University Samarinda, not all students could not do and understand the correct service. The author sees many students who have not been able to do good and correct service and based on badminton rules, service is the initial capital to be able to win the match. In other words, a player cannot get a point if he cannot serve well. Many players also don't pay attention to training and mastering these basic techniques. We know that numbers will not be created if the player is not good at serving correctly according to Deni Danuaji (2007: 29). Seeing that fact, it's suspected that there are fundamental factors achievement for Physical Education students class of 2017
Mulawarman University Samarinda, one of the factors that's thought to be very dominant as an obstacle is the technical aspect itself. This aspect is the service technique.

By looking at the description above, it is suspected that there is a close comparison between how to hold someone's racket and the ability to serve badminton. This is what encourages researchers to conduct research in order to know for sure from these allegations, so the authors are interested in conducting research with the title: "The effect of the forehand grip and back hand grip on the long service ability of badminton in students".

\section{METHODS}

This research type, using field experimental research aims to determine the effect of exercise with forehand grip and the backhand grip grip on the short serve badminton game for Physical Education students, class of 2017 Mulawarman University, Samarinda. This research was conducted from July to September 2019, in Tsamara Samarinda badminton field. The research variables are the properties that will be examined from the samples that have been prepared. The variables to be examined in this study are service exercises with a forehand grip and service exercises with a backhand grip. The dependent variable: The short service ability of the research design used is "Population Pretest-Posttest Design." The population is a group or group of individuals who can observed by members of the population itself or by people who have concerns about it.

According to Sugiyono (2011: 61) that population is a generational area consisting of: objects or subjects that have certain qualities and characteristics that are 
determined by researchers to be studied and then conclusions are drawn and sample is part of the number and characteristics of the population. According to Sugiyono (2011: 62). Based on experts opinions above, the population of this study was all students of Physical and Recreation Education 2017 Samarinda, totaling 40 people. Due to the limited number of population, all of it were used as research samples, so the sampling method used was census technique or saturated sampling. 40 students who were the research sample, they were divided into two groups.

\section{RESULT}

Based on the group A's pretest and posttest results, it's known that forehand service training on short service ability in badminton in badminton is as follows.

Table 1 Results of descriptive analysis of short forehand service exercises

\begin{tabular}{cccccccc}
\hline $\begin{array}{c}\text { Gro } \\
\text { up } \\
\text { (A) }\end{array}$ & $\mathrm{N}$ & $\begin{array}{c}\text { Me } \\
\text { an }\end{array}$ & $\begin{array}{c}\text { Ra } \\
\text { ng } \\
\text { e }\end{array}$ & $\begin{array}{c}\text { M } \\
\text { ax }\end{array}$ & $\begin{array}{c}\text { Mi } \\
\text { n }\end{array}$ & $\begin{array}{c}\text { Dev } \\
\text { iatio } \\
\text { n }\end{array}$ & $\begin{array}{c}\text { Var } \\
\text { ianc } \\
\text { e }\end{array}$ \\
\hline Pre & 2 & 32, & 53. & 66 & 13 & 12.9 & 166, \\
test & 0 & $\begin{array}{c}350 \\
0\end{array}$ & 00 & .0 & .0 & 178 & 871 \\
\hline Pos & 2 & 52, & 46 & 77 & 31 & 12.8 & 165, \\
ttes & 0 & 600 & 46. & .0 & .0 & 734 & 726 \\
t & 0 & 00 & 0 & 0 & 7 & \\
\hline
\end{tabular}

Table 1 above shows the calculation of the average, standard deviation, variance, highest value, lowest value and scores range of initial test and final test of short service ability in badminton forehand service practice game, the initial test obtained an average of 32,3500, standard deviation 12.91786, variant 166,871 and the highest value of 66.00 and the lowest value of 13.00 so that the value obtained is between the highest value minus the lowest value of 66.00 Whereas the final test score for the forehand service practice is obtained an average of 52,6000, standard deviation 12.87347, variant 165.726 and the highest value is 77.00 and the lowest value is 31.00 so that the value is obtained between the highest value minus the lowest value with the lowest value of 46.00 .

Forehand grip short serve training group

Based on the descriptive results of group B pretest and posttest data, it is known that backhand grip service training on the short service ability of badminton is as follows:

Table 2 Results of descriptive analysis of backhand grip service exercises

\begin{tabular}{|c|c|c|c|c|c|c|c|}
\hline $\begin{array}{l}\text { Gro } \\
\text { up } \\
\text { (B) }\end{array}$ & $\mathrm{N}$ & $\begin{array}{c}\mathrm{Me} \\
\text { an }\end{array}$ & $\begin{array}{c}\mathrm{Ra} \\
\mathrm{ng} \\
\mathrm{e}\end{array}$ & $\begin{array}{l}\text { M } \\
\text { ax }\end{array}$ & $\begin{array}{c}\mathrm{Mi} \\
\mathrm{n}\end{array}$ & $\begin{array}{c}\text { Std. } \\
\text { Dev } \\
\text { iatio } \\
n\end{array}$ & $\begin{array}{c}\text { Var } \\
\text { ianc } \\
\mathrm{e}\end{array}$ \\
\hline $\begin{array}{l}\text { Pre } \\
\text { test }\end{array}$ & $\begin{array}{l}2 \\
0\end{array}$ & $\begin{array}{c}32, \\
150 \\
0\end{array}$ & $\begin{array}{c}47 \\
00\end{array}$ & $\begin{array}{c}61 \\
.0 \\
0 \\
\end{array}$ & $\begin{array}{c}14 \\
.0 \\
0\end{array}$ & $\begin{array}{c}12.5 \\
960 \\
5\end{array}$ & $\begin{array}{l}158, \\
661\end{array}$ \\
\hline $\begin{array}{c}\text { Pos } \\
\text { ttes } \\
\mathrm{t}\end{array}$ & $\begin{array}{l}2 \\
0\end{array}$ & $\begin{array}{c}48, \\
100 \\
0\end{array}$ & $\begin{array}{c}42 . \\
00\end{array}$ & $\begin{array}{c}75 \\
.0 \\
0\end{array}$ & $\begin{array}{c}33 \\
.0 \\
0\end{array}$ & $\begin{array}{c}11,9 \\
644 \\
2\end{array}$ & $\begin{array}{l}143 \\
147\end{array}$ \\
\hline
\end{tabular}

Table 2 above shows the calculation of the average, standard deviation, variance, highest score, lowest score and range of scores for the initial and final badminton short service skills of the 2017 Physical Education Skills students at the Samarinda University in the short backhand service exercise. In group (B) short backhand serve exercise, the initial test obtained an average of 32.1500 , a standard deviation of 12.59605 , a variance of 158.661 and the highest value was 61.00 and the lowest value was 14.00 so that the value obtained is between the highest values minus the lowest value of 14.00. Whereas in final test score backhand short 
service practice an average of 48,1000 , standard deviation 11,96442 , variance 143,147 and the highest value of 75.00 and the lowest value of 33.00 so that the value obtained is between the highest value minus the lowest value of 42.00 .

\section{Analysis of Kolmogorov Smirnov Test} Data

After the average value and standard deviation of the two sample groups are known, the next step is to test the normality of the test data using the Kolmogorov-Smirnov test. The goal is to establish a hypothesis testing technique, namely if the data is normally distributed, then it uses parametric paired sample t-test and vice versa if the data is not normally distributed, then it uses non-parametric testing. The results of testing group A forhand short servie exercises can be seen in table 3, as follows:

Table 3 Kolmogorov Smirnov Testing Results Group A

\begin{tabular}{cccc}
\hline $\begin{array}{c}\text { Group } \\
\mathrm{A}\end{array}$ & $\begin{array}{c}\text { Kolmogoro } \\
\mathrm{v}-\text { Smirnov } \\
\mathrm{Z}\end{array}$ & $\begin{array}{c}\text { Asymp } \\
\text {. Sig. } \\
(2- \\
\text { tailed })\end{array}$ & $\begin{array}{c}\text { Conclusio } \\
\mathrm{n}\end{array}$ \\
\hline Pretest & 0.122 & 0.200 & Normal \\
\hline $\begin{array}{c}\text { Posttes } \\
\mathrm{t}\end{array}$ & 0.199 & 0.036 & Normal \\
\hline
\end{tabular}

Based on table 3 above, it shows that the study results show that Kolmogorov Smirnov Z score of initial test was 32.3500 and the final test was 52.6000 which were given short forehand serve exercises. Asymp Value. Sig. (2tailed) initial test 0.200 and final test 0.036. In accordance with the criteria for testing the Asymp value. Sig. (2tailed) the initial test of 0.200 and the final test of 0.036 which were found to be greater than 0.05 with a significant level so that the research data can be said to be normal and the analysis technique of parametric paired sample t-test can be performed.

Kolmogorov Smirnov test in group B backhand short serve exercise can be seen in table 4 below.

Table 4 Kolmogorov Smirnov Test Results Group B

\begin{tabular}{cccc}
\hline $\begin{array}{c}\text { Group } \\
\text { B }\end{array}$ & $\begin{array}{c}\text { Kolmogoro } \\
\text { v-Smirnov } \\
Z\end{array}$ & $\begin{array}{c}\text { Asym } \\
\text { p. Sig. } \\
(2- \\
\text { tailed })\end{array}$ & $\begin{array}{c}\text { Conclusi } \\
\text { on }\end{array}$ \\
\hline Pretest & 0.118 & 0.200 & Normal \\
\hline $\begin{array}{c}\text { Postte } \\
\text { st }\end{array}$ & 0.187 & 0.065 & Normal \\
\hline
\end{tabular}

Based on table 4 above shows that the study results obtained the Kolmogorov-Smirnov $Z$ value of the initial test was 32.1500 and the final test was 48.1000. Asymp Value. Sig. (2-tailed) initial test .200 and final test 0.065 . In accordance with the Asymp test criteria. Sig. (2-tailed) the initial test of 0.200 and the final test of 0.200 which were found to be greater than 0.05 at a significant level so that the research data can be said to be normal and the analysis technique of parametric paired sample t-test can be carried out, so that the research hypothesis testing uses a parametric approach.

Parametric independent sample t-test analysis

As can see the results in table 5 below.

Table 4 Homogeneity Test Results

\begin{tabular}{cccccc}
\hline \multirow{3}{*}{$\begin{array}{c}\text { Badmi } \\
\text { nton }\end{array}$} & $\begin{array}{c}\text { Leve } \\
\text { ne }\end{array}$ & df & df & Sig & Informat \\
short & $\begin{array}{c}\text { Stis } \\
\text { tics }\end{array}$ & 1 & 2 & $\cdot$ & ion \\
\cline { 2 - 6 } service & 0.003 & 1 & 38 & $\begin{array}{c}0.9 \\
59\end{array}$ & $\begin{array}{c}\text { Homoge } \\
\text { neous }\end{array}$ \\
\hline
\end{tabular}

From table 5 above, the homogeneity test results show that the data have 
uniformity that is not significantly different from the sig or probability value (0.959) greater than 0.05 so that the data from this study is that all variables have homogeneous variances.

\section{Hypothesis Testing for Group A}

Table 5 Results of the calculation and significance test on the ability to serve short in badminton on sample group who were given forehand service training (A).

\begin{tabular}{|c|c|c|c|}
\hline \multirow{2}{*}{$\begin{array}{l}\text { Paired Forhand } \\
\text { short serve } \\
\text { group t-test (A) }\end{array}$} & tcount & $\begin{array}{c}\text { Sig. } \\
(2- \\
\text { tailed }) \\
\end{array}$ & $\begin{array}{c}\mathrm{t} \text { table } \\
0.05\end{array}$ \\
\hline & 7,818 & 0,000 & 2,818 \\
\hline
\end{tabular}

Based on table 6 above, the research hypothesis to be tested is reject $\mathrm{H} 0$ and accept $\mathrm{H} 1$ if tcount $>$ ttable is at a significant level $\alpha=0.05$ so that there is an effect of forehand service training on short service ability in badminton games for Physical Education students class 2017 Mulawarman University. Meanwhile, accept $\mathrm{H} 0$ and reject $\mathrm{H} 1$ if tcount <ttable at the significant level $\alpha=0.05$ so that there is no effect of forehand service training on short service abilities in badminton. And reject $\mathrm{H} 0$ and accept $\mathrm{H} 1$, if Sig. (2-tailed) $<\alpha=0.05$ significant level so that there is an effect of forehand service training on short service abilities on students. Meanwhile, accept $\mathrm{H} 0$ and reject $\mathrm{H} 1$ if Sig. (2-tailed) $>\alpha=0.05$ significant level so that there is no effect of forehand service training on the short service ability of students. Based on hypothesis testing about the effect of forehand grip service training on the short service ability of students. In accordance with the criteria for testing the hypothesis, a decision on the $\mathrm{t}$ count value of 7.818 can be taken greater than $\mathrm{t}$ table 2.818 so that $\mathrm{H} 0$ is rejected and $\mathrm{H} 1$ is accepted or it can be said that there is a significant effect of forehand service training on the short service ability of badminton. While testing the sig value the
Sig value is obtained. (2-tailed) 0.000 is smaller than 0.05 so that $\mathrm{H} 0$ is rejected and $\mathrm{H} 1$ is accepted.

Table 6 Results of calculation and significance test on the ability to serve short in badminton in the sample group who were given backhand serve training (B).

\begin{tabular}{cccc}
\hline Paired t-test & tcount & $\begin{array}{c}\text { Sig. } \\
(2- \\
\text { tailed) }\end{array}$ & $\begin{array}{c}\text { t table } \\
0.05\end{array}$ \\
\cline { 2 - 4 } $\begin{array}{c}\text { Backhand short } \\
\text { serve practice } \\
\text { group (B) }\end{array}$ & 10,747 & 0.000 & 2,746 \\
\hline
\end{tabular}

Based on table 7, above the research hypothesis to be tested is to reject $\mathrm{H} 0$ and accept $\mathrm{H} 1$ if tcount $>$ ttable at a significant level. $\alpha=0.05$ so that there is an effect of backhand grip training on short serve strokes in students. Meanwhile, accept $\mathrm{H} 0$ and reject $\mathrm{H} 1$ if tcount <ttable at a significant level $\alpha=0.05$ so there's no effect of short backhand service training on the ability to serve short badminton games. And reject $\mathrm{HO}$ and accept $\mathrm{H} 1$ if Sig. (2tailed) $<\alpha=0.05$ significant level so that there is an effect of backhand short serve training on badminton short serve ability. Meanwhile, accept $\mathrm{H} 0$ and reject $\mathrm{H} 1$ if Sig. (2-tailed) $>\alpha=0.05$ significant level so that there is no effect of backhand short serve training on the short service ability of students.

Based on hypothesis testing about the backhand practice service practice effect on the short service ability of badminton. In accordance with the criteria for testing the hypothesis, a decision on the value of $t$ count 10.747 is greater than $t$ table 2.746 so that $\mathrm{H} 0$ is rejected and $\mathrm{H} 1$ is accepted or it can be said that there is an effect of backhand short service training on the short service ability of badminton play significantly. While the sig value test obtained Sig. (2-tailed) 0.000 is smaller 
than 0.05 so that $\mathrm{H} 0$ is rejected and $\mathrm{H} 1$ is accepted.

Table 7 Difference test results

\begin{tabular}{cccc}
\hline Independent & & \multicolumn{1}{c}{ Sig. } & t table \\
Sample t-test & tcount & $(2-$ & 0.05 \\
group $(A)$ and & & tailed) & 0.05 \\
\cline { 2 - 4 } group $(B)$ & 0.050 & 0.961 & 0.025 \\
\hline
\end{tabular}

Based on table 8 above, the research hypothesis to be tested is reject $\mathrm{H} 0$ and accept $\mathrm{H} 1$ if tcount $>$ ttable at a significant level $\alpha=0.05$ so that there is a difference in the effect of forhand grip and backhand grip on badminton short serve. Meanwhile, accept $\mathrm{H} 0$ and reject $\mathrm{H} 1$ if tcount $<$ ttable at a significant level $\alpha=0.05$ so there is no difference in the effect of the forehand grip and backhand grip on the short service ability of badminton. And reject $\mathrm{H} 0$ and accept $\mathrm{H} 1$ if Sig. (2-tailed) $<\alpha=0.05$ significant level so that there is no difference in the effect of the forehand grip and backhand grip on the short service of badminton ability.

Based on hypothesis testing about the difference in the effect of the forehand grip and backhand grip on short service of badminton ability. In accordance with the criteria for testing the hypothesis, a decision on the value of $t$ count 0.050 is greater than table 0.025 so that $\mathrm{HO}$ is rejected and $\mathrm{H} 1$ is accepted or it can be said that there is a difference in the training effect of the forehand grip and backhand grip on the significant short service ability of badminton. While testing the sig value, the Sig (2-tailed) value of 0.961 is smaller than 0.05 so that $\mathrm{H} 0$ is rejected and $\mathrm{H} 1$ is accepted.

To prove the difference, it can be seen from the average value of the final test in performing badminton short serve abilities. The average score of the forehand short serve training group was 52.6000 and the backhand short serve exercise group average score (B) was 48.1000 or these results indicate that the average forehand short serve exercise final test (A) is better than the final test exercise. Backhand short service (B), thus there is a difference in the effect of forehand grip and backhand grip training on the short service ability of badminton.

\section{DISCUSSION}

Based on the research data, it's stated that there is an effect of the forehand grip and backhand grip on the short service ability of badminton in students. Forehand short serve exercises have a better impact than backhand short serve exercises. This happens because during the short forehand service exercise the movement is the same as the movement for serving in badminton, that is because students prioritize accuracy in performing short services towards the target, namely in the form of a specified angle line which is used as a short serve target, so that occurring in this exercise is an increase in badminton short serve.

In forehand service training, the movements are the same as when doing short serves in badminton, but the implementation of the exercise prioritizes accuracy, so that when performing short services it only focuses on accuracy in students doing short serves and this makes maximal result in performing short serves in the game. Badminton shuttlecock practice should be held lower than when performing a single deep serve so that the time between dropping the shuttlecock and hitting is shorter. The shuttlecock is touched by the racket at a height around the player's waist and shorter. The shuttlecock is touched by the racket at a height around the player's waist more to the player's right than in single play. Shuttlecock across the net, not hit during a single deep serve, the 
stroke is made with a light swinging motion made with the wrist still in an outstretched position. There are two reasons for not straightening the wrist, namely: (1). if you hit with the wrist, you will lose control and the shuttlecock will jump a little high when crossing the net so that the opponent will die easily, (2). Keeping your wrists extended, you will avoid the possibility of making a flicking serve. The most important thing to know is that these two forms of training are only a small part of some forms of training that can improve badminton's short serve ability.

\section{CONCLUSION}

Based on data analysis and discussion, the study results can be concluded as follows:

1. There is an effect of forehand grip training on the short service ability of students.

2. There is an effect of backhand grip practice on students' short service ability.

3. There is a difference in the effect of forehand grip and backhand grip training on students' short service ability.

With the conclusions obtained, the suggestions given in this study are as follows:

1. For coaches, teachers and sports coaches, especially in badminton, it is recommended to use forehand short and backhand short serve exercises in practicing short serve skills so that they can get good service results.

2. In order for sports coaching especially in badminton clubs (PB) in Samarinda to achieve maximum results, it is necessary to advise coaches and officials to prepare adequate supporting facilities and infrastructure, especially those that support athletes' activities in exploring their skills during a training season.

3. For students, it is recommended to know and develop elements of forehand short serve training and backhand grip grip exercises to improve short service abilities and pay attention to anthropometric elements of the body which weren't observed in this study.

\section{REFERENCE}

Akhsan, H. 2012. Mahir Bulutangkis. Bandung: Nuansa Cendekia.

Arikunto, S. 2010. Prosedur Penelitian Suatu Pendekatan Praktik. Jakarta: PT Rikena Cipta.

Arisman, A, \& Saripin, S. 2018. Hubungan kelentukan pergelangan tangan dan power otot lengan-bahu dengan hasil akurasi smash bulutangkis putra pada PB. Angkasa Pekanbaru. Journal of Sport Education, 1(1), 9-16.

Bagaskara, E. 2017. Pengaruh Latihan Smash Sasaran Tetap Dan Sasaran Berubah Terhadap Peningkatan Kemampuan Smash Pada Atlet Bulutangkis Di Pb Ac Quality Yogyakarta. Pend. Kepelatihan Olahraga-S1,1(6).

http://journal.student.uny.ac.id/ojs/ojs/in dex.php/pko/article/download/9057/870

7. diakses 25 Agustus 2019

Budiwanto, S. 2013. Dasar-dasar Teknik dan Taktik Bermain Bulutangkis. Malang: Universitas Negeri Malang.

Deni Danuaji, 2007. Bulu tangkis, IKPI : PT. Indah Jaya Adipratama.

Desmita. 2015. Psikologi Perkembangan Peserta Didik. Bandung: PT. Remaja Rosdakarya.

Juang, B. R. 2015. Analisis Kelebihan dan Kelemahan Keterampilan Teknik Bermain Bulutangkis pada Pemain Tunggal Putra Terbaik Indonesia Tahun 2014. 
Kholison, F., \& Defliyanto, D. (2018). PENGARUH LATIHAN DRILL TERHADAP KEMAMPUAN SERVIS BACKHAND BULUTANGKIS SISWA MTS TARBIYAH ISLAMIYAH KECAMATAN AIR NAPAL BENGKULU UTARA. Kinestetik: Jurnal Ilmiah $P$

Kristiyanto, A. 2010. Penelitian Tindakan Kelas (PTK) Dalam Pendidikan Jasmani \& Kepelatihan Olahraga. Surakarta: UNS Press.

Prayadi, H. Y., \& Rachman, H. A. 2013. Pengaruh Metode Latihan Dan Power Lengan Terhadap Kemampuan Smash Bulutangkis. Jurnal Keolahragaan, 1(1), 63-71. https://doi.org/10.21831/jk.v1i1.2346. diakses 5 September 2019

Pujianto, A. 2012. Modifikasi Pegangan Raket untuk Meningkatkan Kemampuan Teknik Pegangan Bulutangkis. Media Ilmu Keolahragaan Indonesia, 2(1). http://journal.unnes.ac.id/nju/index.php/ miki/article/view/2548. diakses 3 September 2019

Rahyubi, H. 2014. Teori-teori Belajar dan Aplikasi Pembelajaran Motorik. Bandung: Nusa Media.

Ramadhani, K. 2015. Pendidikan Kepelatihan Olahraga Fakultas Ilmu Keolahragaan Universitas Negeri Semarang. Semarang: FIK UNS.

Sarwono. 2011. Psikologi Olahraga. Jakarta: PT. Raja Grafindo Persada.

Sudijono. 2014. Pengantar Statistik Pendidikan. Jakarta: PT. Raja Grafindo Persada.

Sugiyono. 2011. Statistik untuk penelitian. Bandung: CV. Nuansa Cendekia.

Sukadiyanto \& Muluk, D. (2011). Pengantar teori dan metodologi melatih fisik.Bandung: Lubuk Agung

Sukamti, E, R. 2011. Perkembangan Motorik. Yogyakarta: FIK UNY.

Tamim, M. H. 2017. Pengaruh metode latihan (resiprokal dan inklusi) persepsi kinestetik terhadap teknik overhead lob forehand bulu tangkis.

Winarno. 2011. Metodologi Penelitian Dalam Pendidikan Jasmani. Malang: Media Cakrawala Utama Press.Yuliawan, D.
2017. Bulutangkis Dasar. Yogyakarta: CV Budi Utama. 